Case Report

\title{
BENIGN TRANSIENT HYPERPHOSPHATASEMIA - A CAUSE FOR ALARM OR A BENIGN CONDITION
}

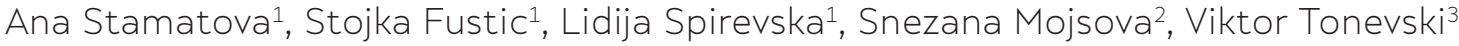 \\ University Clinic of Pediatric Diseases, Skopje; Faculty of Medicine, Ss Cyril and Methodius University, \\ Skopje, Republic of North Macedonia \\ Primary health-care facility "Dr. Mojsova" Bitola, Republic of North Macedonia \\ Primary health-care facility "Dr. Paskalov" Skopje, Republic of North Macedonia
}

\begin{abstract}
Citation: Stamatova A, Fustic S, Spirevska L, Mojsova S, Tonevski V. Benign transient hyperphosphatasemia - a cause for alarm or a benign condition Arch Pub Health 2020; 12 (3).

doi.org/10.3889/aph.2020.5610

Key words: alkaline phosphatase, hyperphosphatasia, benign, transient

*Correspondence: Ana Stamatova. University Clinic of Pediatric Diseases, Skopje, Republic of North Macedonia E-mail: anastamatova@yahoo. com

Received: 21-Oct-2020; Revised: 1-Dec-2020; Accepted: 13-Dec-2020; Published: 15-Dec-2020 Copyright: ${ }^{-}$2020. Ana Stamatova, Stojka Fustic Lidija Spirevska, Snezana Mojsova, Viktor Tonevski This is an open-access article distributed under the terms of the Creative Commons Attribution License, which permits unrestricted use, distribution, and reproduction in any medium, provided the original author(s) and source are credited.

Competing Interests: The author have declared that no competing interests
\end{abstract}

\section{Abstract}

\section{Студија на случај}

Benign transient hyperphosphatasemia (BTH) is a condition which occurs in children younger than five years, characterized by a complete absence of specific clinical and laboratory findings of bone or liver diseases and a five or even 20-70-fold increase in serum of alkaline phosphatase levels(ALP). The aim of this case report was to point out that elevated levels of ALP are not always related to serious bone and liver diseases. We described three healthy patients, which were referred to our out-patient clinic by their primary care physicians because of markedly elevated levels of ALP. The diagnosis of BTH was based on a thorough physical exam, a wide range of laboratory and imaging tests, which excluded liver or bone disease as a cause for elevated ALP. BTH is not very well-known and managed in daily clinical practice. Primary care physicians should consider this diagnosis in cases with elevated ALP in otherwise healthy infants and toddlers, refrain from unnecessary tests, prescribing higher doses of vitamin D3 or referral to tertiary level pediatric institutions.

\section{БЕНИГНА ТРАНЗИТОРНА ХИПЕРФОСФАТАЗИЈА- ПРИЧИНА ЗА ВОЗНЕМИРУВАҢЕ ИЛИ БЕНИГНА СОСТОЈБА}

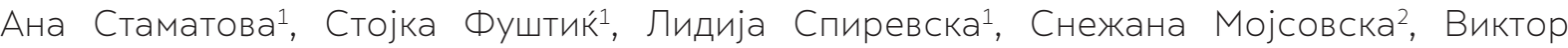 \\ Тоневски

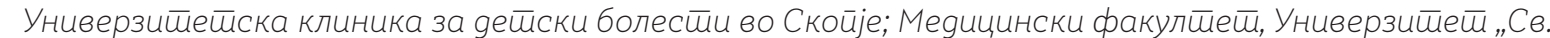 \\ Кирил и Мейоgиj", Скойје, Рейублика Северна Макеgонија

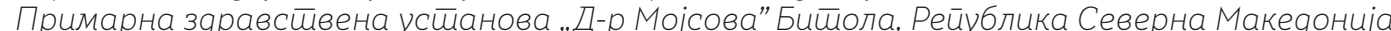 \\ Примарна зуравсӣвена усйанова „Д-р Паскалов" Скойје, Рейублика Северна Макеgонија
}

Цитирање: Стаматова А, Фуштиќ С, Спиревска Л, Мојсовска С, Тоневски В. Бенигна транзи торна хиперфосфатазија- причина за вознемирување или бенигна состојба. Арх Ј Здравје 2020;12(3)

doi.org/10.3889/aph.2020.5610

Клучни зборови: алкална фосфатаза, хиперфосфатазија, бенигна, транзиторна

*Кореспонденција: Ана Стаматова, Универ зитетска клиника за детски болести во Скопје, Скопје, Република Северна Македонија. E-mail: anastamatova@yahoo.com

Примено: 21-окт-2020; Ревидирано: 1-дек-2020; Прифатено: 13-дек-2020; Објавено: 15-дек-2020

Печатарски права: 2020 Ана Стаматова Стојка Фуштиќ, Лидија Спиревска, Снежана Мојсовска, Виктор Тоневски. Оваа статија е со отворен пристап дистрибуирана под условите на недокализирана лиценца, која овозмовув неггеничена употреба, дистрибуциј и регронегган ц ат оригиналниот(ите) автор(и) и изворот.

Конкурентски интереси: Авторот изјавува дека нема конкурентски интереси.

\section{Извадок}

Бенигната транзиторна хиперфосфатазија (БТХ) е состојба која се јавува кај деца помлади од пет години. Се карактеризира со целосно отсуство на специфични клинички и лабораториски наоди за болести на коските и црниот дроб и пет или дури 20-70 пати поголемо зголемување на серумското ниво на алкална фосфатаза (АЛП). Целта на овој приказ на случаи беше да се истакне дека случаен наод на покачено серумско ниво на АЛП не е секогаш поврзано со сериозни заболувања на коските и црниот дроб. Опишавме три здрави пациенти, кои беа упатени во нашата амбуланта од страна на лекари од примарната здравствена заштита поради значително зголемено ниво на АЛП. Дијагнозата на БТХ беше заснована на темелен клинички преглед, широк спектар на лабораториски тестови, со што беа исклучени заболувања на црниот дроб и коските како причина за покачена АЛП. БТХ е состојба која не е добро позната и менаџирана во секојдневната клиничка пракса. Лекарите од примарната здравствена заштита треба да ја имаат предвид оваа дијагноза во случаи со покачена АЛП кај здрави доенчиња и мали деца и да се воздржат од правење непотребни тестови и препишување повисоки дози на витамин Д了. 


\section{Introduction}

Alkaline phosphatase (ALP) is one of the most commonly ordered laboratory tests used to evaluate the presence of rickets, bone or liver disorders in pediatric patients. ALP is an enzyme present in placenta,intestinal mucosa, kidney, bone and liver, but the majority of the alkaline phosphatase in serum (more than 80\%) is released from liver and bone, and in small amounts from the intestine ${ }^{1}$. It is represented by four isoenzymes produced by bone, liver, intestine and kidney, which take part in important metabolic processes like: IgG transportation during pregnancy, bone formation, renal and intestinal phosphate transportation, fat transportation and pancreatic chlorine channels regulation ${ }^{1-3}$. The serum ALP levels vary by age, with significantly higher levels in toddlers and young children compared to levels in adulthood 4. Although serum ALP levels are a sensitive marker for bone and liver diseases in children and adults, there is a condition that is usually found incidentally in young children, which is characterized by a complete absence of specific clinical and laboratory findings of bone and liver diseases and a fivefold or even 20-70-fold increase in serum ALP. This condition is known as benign transient hyperphosphatasemia $(\mathrm{BTH})^{2-4}$. Although there is growing scientific evidence in the current literature suggesting this is a completely benign cause of excessively elevated ALP, it remains a condition under-recognized and not very well managed. It is important to avoid the unnecessary investigations or over treatment in patients with significant increase in ALP levels.
The objective of this study was to describe three healthy patients, which were referred to our out-patient clinic by primary care physicians because of markedly elevated levels of ALP. The diagnosis of BTH in our patients was based on their clinical and biochemical features, meaning a thorough physical exam and a wide range of laboratory and imaging tests in order to rule out liver or bone disease as a cause for elevated ALP.

\section{Case reports}

We describe the case history of three patients who were referred to our outpatient clinic in the period from 2018 to 2020. The mean age of the patients was 19.3 (13-25) months; two were girls and one was boy. All three toddlers were referred under suspicion of having rickets because of elevated ALP. The first patient, a 13-month-old boy,, was referred to the outpatient clinic by the child's primary care physician because the child was still unable to walk without support. The child was initially referred to an orthopedist who prescribed cholecalciferol 4000 IU per day. The second patient, a 20-month-old girl had an open anterior fontanelle, with measures $1 \mathrm{x}$ $1 \mathrm{~cm}$ and was prescribed cholecalciferol 6000 IU per day. The third patient, a 25-month-old girl had a slight varus deformity of the lower limbs, which prompted the primary care physician to seek consultation. All children were healthy; physical examination was performed, which showed that their anthropometric measures were within the normal range for their age and sex (Table 1). 


\begin{tabular}{|l|c|c|c|}
\hline & Patient 1 & Patient 2 & Patient 3 \\
\hline age & 13 months & 20 months & 23 months \\
\hline sex & male & female & female \\
\hline Height Z score & +1.5 & +1 & +1.8 \\
Weight Z score & +0.8 & +1.2 & +1.6 \\
\hline AST (N.15-59 U/L) & 13 & 25 & 18 \\
\hline ALT (N.9-72U/L & 10 & 15 & 27 \\
\hline GGT (N.0-36U/L) & 9 & 30 & 28 \\
\hline LDH(N.0-500U/L) & 344 & 284 & 249 \\
\hline Ca (N.2.10-2.55 mmol/L) & 2.20 & 2.15 & 2.43 \\
\hline P(N.0.85-2.15mmol/L) & 1.5 & 2.02 & 1.8 \\
\hline Mg (N.0.70-1.0mmol/L & 0.8 & 0.98 & 1.1 \\
\hline BUN (N.2.6-6.4mmol/L) & 3.5 & 4.9 & 6.0 \\
\hline Creatinine(N.0-104mmol/L) & 60 & 54.4 & 75 \\
\hline ALP(N.0-120U/L) & 2050 & 2800 & 3400 \\
\hline 25(OH)Vit D3(N.20-50ng/ml) & 33 & 45 & 20 \\
\hline PTH(N.10-65pg/ml) & 40 & 24 & 60 \\
\hline
\end{tabular}

alanine aminotransferase (ALT), aspartate aminotransferase (AST), gamma-glutamyl transpeptidase (GGT), calcium (Ca), phosphate (P), magnesium (Mg), blood urea nitrogen (BUN), 25-hydroxy vitamin D3, parathormone (PTH)

Table 1. Anthropometric characteristics and results from laboratory tests in our patients

They did not have frontal bossing, widening of the wrists or other bone deformities suggesting rickets or other bone disorders. There was no history of dark-colored urine, pruritus, and steatorrhea. The medical history of all three patients contained information that the children had a viral gastroenteritis two weeks prior to the measured elevated ALP.

A wide panel of laboratory test was performed, including: alanine aminotransferase (ALT), aspartate aminotransferase (AST), gamma-glutamyl transpeptidase (GGT), calcium, phosphate, magnesium, blood urea nitrogen, creatinine, ALP, 25-hydroxy vitamin D3, PTH and a wrists $\mathrm{x}$-ray. All of the results were within normal range, excluding the levels of ALP which were markedly elevated (Table1). The ALP was measured using a biochemical analyzer (Architect c4000 Abbot) with a colorimet- ric assay, based on the conversion of para-nitrophenyl phosphate.The reference value for children up to 5 years old is from 81.9 to $350.3 \mathrm{U} / \mathrm{L}$. The maximum values of ALP recorded in the three patients were: 3400,2800 and $2050 \mathrm{UI} / \mathrm{L}$, respectively. The children were prescribed a prophylactic dose of cholecalciferol. On the first follow-up visit after two months, the level of ALP was reduced significantly in all three toddlers, compared to their first visit (850, 670 and 600 IU/L, respectively). The next followup at four months, the ALP levels of all the three patients had completely normalized (180, 120 and 115 IU/L, respectively). By the end of the followup period the first patient was able to walk without support and the anterior fontanel of the second patient had closed completely. 


\section{Discussion}

BTH is a cause for markedly elevated ALP levels in childhood, but it is a transient, completely benign condition which requires no specific treatment (5). In a study by Suzuki et al. from 2002, it was suggested that the most probable cause for BTH was a recent enteroviral infection ${ }^{6}$, while other studies have suggested that this condition is a biochemical problem rather than an illness $7,8,9$. The first description of this condition was made by Bach in 19545, but the diagnostic criteria were defined years later, in 1985 by Kraut et al ${ }^{10}$ and they include: age of presentation less than five years; no other evidence for bone or liver disease on physical examination or laboratory findings; elevation in both bone and liver ALP isoenzymes; and normalization of serum ALP levels within four months. A presumptive diagnosis of BTH was made by Chu et al. ${ }^{11}$, which incorporated Kraut's original diagnostic criteria, but updated with more recent relevant literature, including ALP levels significantly elevated (median values nine-fold the upper limit of normal), which return to normal within 3 to 4 months; age less than five years; history and physical examination non-confirmatory for bone or liver disease; normal liver tests; normal electrolytes, blood urea nitrogen and creatinine; an absolute elevation of both bone and liver fractions of ALP isoenzymes; normal levels of PTH and 25-hydroxy vitamin $\mathrm{D}$. The clinical course and the ALP levels of the patients described in this study were similar to those reported in the published literature ${ }^{4-6}$. The evaluation of the patient with a detailed history, a thorough physical examination and baseline laboratory tests is generally sufficient to exclude possible liver or bone disease. The primary diag- nostic concerns when encountering elevated ALP levels in children include: bone disorders, liver disease, less commonly kidney disease and drug reactions (anticonvulsants, antibiotics $)^{7,8}$. Specific inquiries should be made about the presence of symptoms indicating hepatobiliary disease and signs of rickets ${ }^{8}$. Compared to other causes for elevated ALP, the peak value of ALP in BTH can be from 3 to 30-fold above upper reference range ${ }^{7}$. According to a recent study, the ALP was elevated at least 5 times from the upper normal limit in $71 \%$ of patients with $\mathrm{BTH}^{12}$. It has been suggested that intermediate elevations of less than 5 times than normal may possibly represent either developing or resolving $\mathrm{BTH}^{13}$. In our patients, ALP levels were at least nine times higher than normal upper limit (between 2050 and $3400 \mathrm{IU} / \mathrm{L}$ ).

In conclusion, even though almost half a century has passed since the first reported case of BTH in early childhood, it is rarely mentioned in the literature and takes up a small place in textbooks; it is not very wellknown and managed in daily clinical practice. We have reported three cases of toddlers with BTH who are a good example of a basic medicine lesson:"Don't treat the lab results, treat an illness". Primary care physicians should consider this diagnosis in cases with elevated ALP in healthy infants and toddlers, avoid unnecessary investigations, prescribing higher doses of vitamin D3 or referral to tertiary level pediatric institutions.

\section{References}

1. Ridefelt P, Gustafsson J, Aldrimer M, Hellberg D. Alkaline phosphatase in healthy children: reference intervals and prevalence of elevated levels. Horm Res Paediatr 2014; 82(6): 399-404. 
2. Pace AE, Osinde ME. Hiperfosfatasemia transitória benigna de la infância. Uma aproximación diagnóstica racional. Arch Argent Pediatr 1999;97:383-90.

3. Melo MCN, Carneiro NB, Tolaymat $\mathrm{N}$, et al. Hiperfosfatasemia transitória benigna na infância. Rev Cienc Med Biol 2004;3:108-14.

4. Tolaymat N, de Melo MC. Benign transient hyperphosphatasemia of infancy and childhood. South Med J 2000;93:1162-4.

5. Bach U; Das verhalten der alkalischen serumphosphatase bei Frughgerborenen. Rachitikern und Spasmophilen. Z Kinderheilk 1954; 74: 593-609.

6. Suzuki M, Okazaki T, Nagai T, Törõ K, Sétonyi P. Viral infection of infants and children with benign transient hyperphosphatasemia. FEMS Immunol Med Microbiol 2002; 33(3): 215-8.

7. Carroll AJ, Coakley JC. Transient hyperphosphatasaemia: an important condition to recognize. J Paediatr Child Health 2001;37:359-6.

8. Kutilek S, Cervickova B, Bebova P, Kmonickova M, Nemec V. Normal bone turnover in transient hyperphosphatasemia. J Clin Res Pediatr Endocrinol 2012; 4(3): 154-156.

9. Otero JL, Gonzalez-Peralta RP, Andres JM, Jolley CD, Novak DA, Haafiz
A. Elevated Alkaline Phosphatase in children: an algorithm to determine when a "wait and see" approach is optimal. Clin Med Insights Pediatr 2011; 5:15-8.

10. Kraut JR, Metrick M, Maxwell NR, Kaplan MM. Isoenzyme studies in transient hyperphosphatasemia of infancy: ten new cases and a review of the literature. Am J Dis Child 1985; 139(7): 736-40.

11. Chu AS, Rothschild JG. Update on benign transient hyperphosphatasemia: recognizing an underappreciated condition. Clin Pediatr (Phila) 2016; 55(6): 564-6.

12. Gualco G, Lava SA, Garzoni Let al. Transient benign hyperphosphatasemia. J Pediatr Gastroenterol Nutr 2013; 57(2): 167-71.

13. Asanti R, Hultin H, Visakorpi JK. Serum alkaline phosphatase in healthy infants: occurence of abnormality high values without known cause. Ann Paediatr Fenn 1966; 12(2): 139-42. 